Tourism Research Journal

E-ISSN: 2598-9839

2021, Vol. 5 No. 1

\title{
Promotion of Instagram and Purchase Intention: A Case of Beverage Business at Covid-19 Pandemic
}

\author{
Fachrul Husain Habibie*, Amalia Mustika, Heny Ratnaningtyas, Velicia \\ Noveti
}

Trisakti School of Tourism

*fachrul@stptrisakti.ac.id

\begin{abstract}
This study aims to analyze the effect of Instagram promotion on buying interest at Yogo Living World. This study uses a descriptive correlational method with a quantitative approach. The unit of analysis in this study is Yogo Living World consumers with a sample size of 100 individuals using probability sampling techniques. This study uses a simple linear regression test. The results of the descriptive statistical test show that: (1) Instagram promotion is in the fairly interesting category with an average score of 3.81 and (2) purchase intention is in the fairly interesting category with an average score of 3.87 . The coefficient of determination test results show that the promotion factor of Instagram has an effect of $74.1 \%$ on buying interest at Yogo Living World and the remaining $25.9 \%$ is influenced by other factors that are not examined. The $\mathrm{t}$ test shows that Instagram promotion has a significant effect on buying interest at Yogo Living World. The culinary business is promoted through social media, especially Instagram, which can describe product profiles ranging from taste, appearance and service through videos displayed on social media. In Instagram promotions, the hashtag indicator adds hashtag variations, the number of hashtags, and provides special promotions for customers who use hashtags.
\end{abstract}

Keywords: Promotion of Instagram, Purchase Intention, Yogo Living World

Tourism Research Journal, Volume 5 (1), 2021 


\section{A. Introduction}

According to a report by www.NapoleonCat.com, a social media marketing analyst firm based in Warsaw, Poland, 22.6 percent, or nearly a quarter of Indonesia's total population, are Instagram users. This number slightly increased from the previous month, which said that the total number of Instagram users in Indonesia reached 59,840,000. Instagram users with the most dominant female gender in Indonesia. Missiles recorded reach 50.8 percent, superior to male users who reached 49.2 percent. Users aged 18-24 years are the largest user age group in Indonesia, with a total proportion of 37.3 percent or around 23 million users. In that age range, female Instagram users are still dominant with a proportion of 19.5 percent compared to men with a proportion of 17.9 percent. The second largest user is in the age group 25-34 with a proportion of 33.9 percent. In contrast to the previous age, the age category was superior to male users by 17.9 percent, while female users were 16.1 percent. Meanwhile, in terms of numbers, male users are superior to 1.1 million. The lowest age category is over 65 years which is only 1.6 percent (NapoleonCat, 2021).

Share creative content about their life. In fact, their existence had a profound influence on their followers, who mostly teenagers. Therefore, teenagers are easily tempted to adopt something viral as it looks prestigious (Huang \& Copeland, 2020). Now social media is not only used as a means of communication and interaction. The number of Instagram users makes business people interested in marketing their products to reach and approach potential customers, and to learn more about customers and expand brand reach (Astuti \& Putri, 2018). The ease of interacting with potential consumers makes it easier for the distribution of products from one account to another to be faster and viral. Sellers can receive feedback from customers faster with the direct message feature and the comments column available on upload. This helps sellers determine the level of customer satisfaction with their products or services (Aji et al, 2020).

In this culinary business competition, sellers are required to be able to present the best products or services, competitive prices, strategic, and comfortable places to attract consumers. One of which is Yogo Living World. Given that consumers are the "King", consumers are free to determine where they will buy the beverage product they will choose. Moreover, Jakarta has many beverage outlets, from small businesses to franchises, providing. Coffee, Thai Tea, Cold Pressed Juice, Bubble drinks and others.

This contemporary drink has become part of the lifestyle of the Indonesian people, especially in a metropolitan city like Jakarta, thus opening up huge opportunities for business people in Indonesia to open a business, and there are many beverage outlets whose names are familiar to the ears Indonesian people (Rahmah et al, 2018). As one of the contemporary drink sellers, Yogo Yogurt Juice, which sells a mixture of juice and bubble products with the guilty free drink concept, must be able to improve product quality and customer satisfaction by maximizing or eliminating unpleasant experiences. When consumers are satisfied with the product, Indirectly, this will greatly help sellers in distributing their products. From here we can see how

Tourism Research Journal, Volume 5 (1), 2021 
the seller must fix the existing problems so that the seller can survive in the midst of intense competition due to the large number of similar beverage products in Jakarta.

The most important thing to be able to survive in the culinary business today is promotion through social media, especially Instagram. Here is one of the Instagram promotion tools from Yogo Yogurt Juice. You can see the number of followers on Instagram@its.yogo is 1,650 followers and the number of posts on Instagram @ its.yogo is 183 .

Nangoy \& Tumbuan (2018), reported that promotion has a huge influence on consumer purchase interest. Purchase interest is someone's desire to decide to buy goods or services. Additionalliy, Kotler and Keller (2012), statted that it refers to consumer behavior where consumers have the desire to buy or choose a product, based on experience in choosing, using and consuming or even wanting a product. product.

\section{B. Literature Review \\ Marketing Management}

Marketing plays an important role in the company because in its implementation it deals directly with consumers and other external environments. Marketing activities are directed at creating exchanges that allow companies to survive. Marketing is a social process in which individuals or groups get what they need and want by creating, offering, and freely exchanging products and services of value with others (Kotler and Keller, 2012).

Marketing management occurs when at least one party in a potential exchange thinks of a way to achieve the desired response with the other party. We therefore view marketing management as the art and science of selecting target markets and reaching, retaining and growing customers by creating, delivering and communicating superior customer value. Marketing is an organizational function and a set of processes for creating, communicating, and providing value to customers and for managing customer relationships in a way, which benefits the organization and its stakeholders. Marketing management is a process to increase the efficiency and effectiveness of marketing activities carried out by individuals and by companies (Halilkainen et al, 2020)

Marketing Management is the science of selecting the appropriate target market, to increase the efficiency and effectiveness of marketing activities carried out by the company, and to establish good relationships with targeted customers (Quinton, 2013).

\section{Digital Marketing}

Digital marketing is a marketing activity including branding that uses various web-based media such as blogs, websites, email, adwords, Instagram, Facebook or social networks (Ibrahim \& Ganeshbabu, 2018). Digital marketing is a promotional activity and market search through online digital media by utilizing various means such as social networking. Digital marketing which usually consists of interactive and

Tourism Research Journal, Volume 5 (1), 2021 
integrated marketing facilitates interactions between producers, market intermediaries and potential consumers (Appel et al, 2019). Digital marketing business people and provides all the needs and desires of potential consumers, on the other hand, potential consumers can also search and get product information just by browsing in cyberspace, making it easier for consumers to find and get product information. search process (Jackson \& Ahuja, 2016). Buyers are now increasingly independent in making decisions based on search results. Digital marketing can reach everyone wherever they are without any limitation or time limit (Bostanshirin, 2014).

\section{Social media}

Social media as an internet-based application that is built on the ideology and technology of web 2.0 and supports the exchange and exchange of content created by users (Kaplan \& Haenlin, 2010). Social media is a website-based feature that can form networks and allow people. On social media, we can carry out various forms of exchange, collaboration and get to know each other in the form of visual and audiovisual writing. For example, like Instagram, Facebook, forsqure and others (Puntoadi, 2011).

Social media can act as an effective business promotion tool because it can be accessed by anyone, so that the promotion network can be wider. Social media is an indispensable part of marketing by many companies and is one of the best ways to reach customers and clients. Social media such as Facebook, blogs, Instagram and YouTube have a number of benefits for companies and are faster than conventional media such as print media and TV advertisements, brochures and flyers (Silvia, 2019).

\section{Types of Social Media}

Types of social media can be differentiated based on the network model used, the characteristics of social media use, or the type of fines that are conveyed and disseminated (sharing). Nasrullah (2015), there are at least 6 major categories to see the distribution of social media, namely:

1. Social networking media (social networks)

This media is a means by which users can make social relations, including the consequences or consequences of these social relationships in cyberspace. The main characteristic of social networking sites is that each user forms a network of friends, either with users they already know and who are likely to meet frequently in the real world (offline) or form new networks of friends.

2. Online Journal (Blog)

Online journals are social media that allow users to upload daily activities, comment on each other, and share, both other web links, information, and so on. The character of a blog, among others, is that its users are private and the content that is published is also related to the users themselves. Content that is built by the blog owner or blogger tends to be the owner's experience. Except for company blogs, it usually includes company activity in the third person.

Tourism Research Journal, Volume 5 (1), 2021 
3. Online or simple journal or microblogging Similar to online journals (blogs), micro blogging is a type of social media that facilitates users to write and publish their activities and opinions. The presence of this type of social media refers to the emergence of Twitter which only provides certain spaces or a maximum of 140 characters.

4. Share media

Sharing media sites is a type of social media that makes it easy for users to share media, ranging from documents (files), video, audio, images and so on.

5. Social bookmark

Social bookmarking is social media that functions to organize, store, manage, and search for certain information or news online.

6. Shared content media or wiki

This social media is a site whose content is the result of collaboration from its users. Similar to a dictionary or encyclopedia, a wiki provides users with meaning, history, book references, or syllable links.

\section{Instagram}

Instagram was created by Kevin Systrom and Mike Krieger, and was founded on October 6, 2010. Instagram is a photo sharing application that allows users to take photos, apply digital filters, and share them on various social networking services, including Instagram itself. Instagram comes from the understanding of the function of this application as a whole. The word "insta" comes from the word "instant", just like the Polaroid camera, which in its time was better known as "instant photo". Instagram can also display photos instantly, as supported by Polaroid. Meanwhile, the word "gram" comes from the word "telegram", which is how it works to send information to other people quickly. Likewise with Instagram, which can upload photos using the internet network, so that the information you want to convey can be received quickly. Therefore, Instagram is a combination of the words insta and telegram. The social system on Instagram is by being a follower of other users' accounts, or having Instagram followers. Thus fellow Instagram users themselves can be intertwined by giving likes and also commenting on photos that have been uploaded by other users. Are is also an element that is no less important, where the number of likes from followers greatly affects whether or not a photo becomes a popular photo. To find friends on Instagram, you can also use their friends who also use Instagram through social networks such as Instagram and Facebook, (Atmoko, 2012).

\section{Instagram features}

1. Hash tag

Hashtag is a sign (\#) that is used when posting to make it easier to find and add followers or likes to uploaded photos. This feature is also used to facilitate the classification of photo types or themes, so that users can find photos with similar themes. Examples of hashtag users include \#flowers in flower photos, and 
\#beaches in beach photos. The use of photo hashtags is a maximum of 30 hashtags, more than that will not be able to be published in the uploaded post.

2. Geotags

Geotag is a feature used to tell the location where the uploaded photo is. When uploading photos, users will be given the option to use the location or not by activating the GPS (Global Positioning System) system on the device. This makes it easier for other users to view photo locations and various other photos from the same location by clicking on the location listed.

3. Follow

Follow is a feature to follow other users. Users can see the uploads of users who have followed the front page of Instagram. From a security standpoint, users can choose closed or open privacy. In closed privacy, only followers who have been accepted by the user can view the account. Meanwhile, in open privacy, other users can freely view and give likes or comments on uploaded photos.

4. Share

Sharing is a feature used to share photos that have been uploaded to other social networks. Like Facebook or Twitter. This feature also gives you the option to enable it or not. When this feature is activated, uploaded photos can appear on other connected social accounts.

5. Like it

Likes is a feature that allows you to like photos that have already been uploaded. This allows users who follow each other to view the photos they like in the browse bar. The more people who like the photos you upload, the more chances to get new followers.

6. Comment

Comments are a feature that is present on every photo that has been uploaded to provide comments. In each account with open privacy, other users can comment on photos and interact with them.

\section{Purchase Intention}

Purchase intention is the desire to own a product, buying interest will arise if consumers are already influenced by the quality and quality of a product, information about the product, for example: price, how to buy and the weaknesses and advantages of the product over the brand (Durianto, 2013). Interest in buying a product that arises because there is a basis for trust in the product accompanied by the ability to buy the product (Simamora, 2011).

Kotler and Keller (2012) mentions several factors that influence consumer behavior in buying an item, as follows:

1. Cultural factors

a. Culture

The most basic determinant of a person's desires and behavior.

b. Culture

Tourism Research Journal, Volume 5 (1), 2021 
Each culture consists of a number of sub-cultures that provide channels and more specific socialization for its members. Sub culture includes nationality, race, ethnicity, religion and group members.

c. Social Class

A group in society, where each group tends to have the same values, interests and behaviors.

2. Social Factors

a. Reference Group

A group that can have direct or indirect influence on a person's behavior and behavior.

b. Family

Family members can have a strong influence on purchasing behavior.

c. Status and Role

The higher the person in a group, the higher the status so that this does not have a direct impact on the buying behavior of a product.

3. Personal factors

a. Age and Life Cycle Stage

A person's purchases of goods or services will vary over their lifetime. Likewise with a person's relationship related to his age.

b. Occupation

Job differences in each individual cause different basic patterns that affect the buying behavior of a product.

c. Economic Condition

A person's economic condition can be seen from the level of income which can affect product selection.

d. Lifestyle

Lifestyle is a person's lifestyle that determines buying behavior.

4. Psychological factors

a. Motivation

A need that is strong enough to be close enough to direct someone to find a way to get the satisfaction of that need.

b. Perception

A person's response to a situation.

c. Learning

Learning describes changes in a person's behavior that come from experiences.

Most human behavior is acquired by studying it.

d. Beliefs and Attitudes

Through action and learning, it acquires beliefs and attitudes, which in turn influence buying behavior. indicators:

Negara, et al (2018) buying interest can be identified through the following

1. Transactional interest, a person's tendency to buy back products that have been consumed.

Tourism Research Journal, Volume 5 (1), 2021 
2. Referential interest, the tendency for someone to reference a product they buy, so that other people buy it, with reference to their consumption experience.

3. Preferential interest is an interest that describes the behavior of someone who has a primary preference for the product. This preference can only be changed if something happens to a product that you like.

4. Explorative interest, this interest describes the behavior of a person who is always looking for information about the product he is interested in and looking for information to support the positive nature of the product.

\section{Framework of Thinking}

In order for product marketing to run well, it is necessary to choose the right strategy. The framework in this study describes the relationship of the independent variable, in this case, social media Instagram $(\mathrm{X})$ to consumer purchase interest $(\mathrm{Y})$.

\begin{tabular}{|c|c|}
\hline $\begin{array}{l}\text { Promotion of Instagram } \\
\text { (X) }\end{array}$ & Purchase Intention $(\mathrm{Y})$ \\
\hline $\begin{array}{l}\text { X1 Hashtag } \\
\text { X2 Geotag } \\
\text { X3 Follow } \\
\text { X4 Share } \\
\text { X5 Like } \\
\text { X6 Comment }\end{array}$ & $\begin{array}{ll}\text { 1. } & \text { Transactional } \\
& \text { Interest } \\
\text { 2. } & \text { Relative Interests } \\
\text { 3. } & \text { Preferential Interests } \\
\text { 4. } & \text { Explorative Interest }\end{array}$ \\
\hline
\end{tabular}

Figure 1. Framework of Thinking

\section{Hypothesis}

$\mathrm{H}_{0}$ : There is no significant effect of Instagram promotion on purchase intention Ha: There is significant effect of Instagram promotion on purchase intention

The difference between this study and previous research is that Instagram features will be the question item on the Instagram promotion variable.

\section{Research Methodology}

The method used in this research is quantitative descriptive which explains how the instrument influences the purchase intention. The research location is a cafe which is quite well known in the Alam Sutera Serpong area, namely in Alam Sutera Living Word Mall under the name Yogo. Yogo is a start-up with a yogurt juice drink business model that is here to offer with various toppings such as bubbles but with the guilt-free concept of pleasure for buyers.

\section{Population and Sample}

In this study, the population size refers to the number of followers of the Instagram@ its.yogo account for 3 months from February to April 2020, namely 
1,650 people. (https://www.instagram.com/its.yogo/). Of the total population, the number of samples in this study were 100 respondents.

\section{Data Collection}

The data collection method used in this research is a questionnaire, the questionnaire technique that the author uses is a closed questionnaire, a way of collecting data by providing or distributing a list of questions to respondents. The sampling technique in this study is a probability sampling technique, which is a sampling technique that provides equal opportunities for each element (member) of the population to be selected as a sample member.

\section{Instrumentation}

Table 1. Instrument Variabel

\begin{tabular}{|c|c|c|}
\hline Variable & Sub Variable & Item Question \\
\hline \multirow{13}{*}{$\begin{array}{l}\text { Promotion } \\
\text { of } \\
\text { Instagram }\end{array}$} & \multirow[t]{2}{*}{ Hashtag } & $\begin{array}{l}\text { I use the hashtag \#LetsSwitchToYOGO to see reviews from } \\
\text { people who come to Yogo Living World }\end{array}$ \\
\hline & & $\begin{array}{l}\text { I will use the hashtag \#LetsSwitchToYOGO when I post } \\
\text { photos of the drinks I have bought }\end{array}$ \\
\hline & \multirow[t]{2}{*}{ Geotag } & $\begin{array}{l}\text { Geotags (Instagram location link) help me gather photo } \\
\text { information about drinks and outlets from people who come } \\
\text { to Yogo Living World }\end{array}$ \\
\hline & & $\begin{array}{l}\text { Geotags (Instagram location link) gave me instructions on } \\
\text { how to find Yogo Living World locations }\end{array}$ \\
\hline & \multirow[t]{2}{*}{ Follow } & $\begin{array}{l}\text { By following Instagram "its.yogo" I got information about } \\
\text { the variants of drinks sold by Yogo Living World }\end{array}$ \\
\hline & & $\begin{array}{l}\text { By following Instagram "its.yogo" I got information about } \\
\text { the promotion of Yogo Living World }\end{array}$ \\
\hline & \multirow[t]{2}{*}{ Share } & $\begin{array}{l}\text { The Instagram Sharing Tool makes it easy for me to share } \\
\text { experiences or information in the feed about Instagram } \\
\text { "its.yogo" }\end{array}$ \\
\hline & & $\begin{array}{l}\text { Share tools Instagram membantu saya membagikan } \\
\text { pengalaman atau informasi di Instastory tentang Instagram } \\
\text { "its.yogo" }\end{array}$ \\
\hline & \multirow[t]{3}{*}{ Like } & $\begin{array}{l}\text { Like Instagram helps me see the popularity of Yogo Living } \\
\text { World on Instagram "its.yogo" }\end{array}$ \\
\hline & & $\begin{array}{l}\text { Like Instagram helps me find out what my favorite drink / } \\
\text { drink is at Yogo Living World }\end{array}$ \\
\hline & & $\begin{array}{l}\text { I found Instagram "its.yogo" or Yogo photos to browse } \\
\text { Instagram that my friends or relatives love }\end{array}$ \\
\hline & \multirow[t]{2}{*}{ Comment } & $\begin{array}{l}\text { I came to Yogo Living World because many followers on } \\
\text { Instagram "its.yogo" gave interesting reviews }\end{array}$ \\
\hline & & $\begin{array}{l}\text { I think the comments column provides information about } \\
\text { the experiences of someone who has visited Yogo Living } \\
\text { World }\end{array}$ \\
\hline
\end{tabular}

Tourism Research Journal, Volume 5 (1), 2021 
Promotion of Instagram and Purchase Intention: A Case of Beverage Business at Covid-19 Pandemic

\begin{tabular}{|c|c|c|}
\hline \multirow[t]{8}{*}{$\begin{array}{l}\text { Buying } \\
\text { Interest }\end{array}$} & \multirow[t]{2}{*}{$\begin{array}{l}\text { Transactional } \\
\text { Interests }\end{array}$} & $\begin{array}{l}\text { I came to Yogo Living World because I saw posts from } \\
\text { family, friends and relatives on Instagram }\end{array}$ \\
\hline & & $\begin{array}{l}\text { After trying the products sold by Yogo Living World, I feel } \\
\text { satisfied and want to come back again }\end{array}$ \\
\hline & \multirow{2}{*}{$\begin{array}{l}\text { Relative } \\
\text { Interests }\end{array}$} & I would recommend Yogo to family, friends and relatives \\
\hline & & $\begin{array}{l}\text { I will share my experience on Instagram after coming and } \\
\text { buying products at Yogo Living World }\end{array}$ \\
\hline & \multirow[t]{2}{*}{$\begin{array}{l}\text { Preferential } \\
\text { Interests }\end{array}$} & $\begin{array}{l}\text { After trying the products sold by Yogo Living World, I feel } \\
\text { that the taste, appearance and service are what I paid for }\end{array}$ \\
\hline & & $\begin{array}{l}\text { After trying the products sold by Yogo Living World, I feel } \\
\text { that the product suits my taste }\end{array}$ \\
\hline & \multirow[t]{2}{*}{$\begin{array}{l}\text { Interests in } \\
\text { Exploration }\end{array}$} & $\begin{array}{l}\text { Before coming to Yogo Living World, I looked for } \\
\text { information about products sold on Instagram "its.Yogo" }\end{array}$ \\
\hline & & $\begin{array}{l}\text { Before trying Yogo Living World, I looked for a menu or } \\
\text { beverage product that was almost the same or similar to } \\
\text { "its.yogo" and compared them on Instagram }\end{array}$ \\
\hline
\end{tabular}

\section{Results}

\section{Respondent Profile}

Table 2. Gender

\begin{tabular}{|c|l|r|r|}
\hline \multicolumn{2}{|c|}{} & Frequency & Percent \\
\hline \multirow{3}{*}{ Valid } & Male & 30 & 30.0 \\
\cline { 2 - 4 } & Female & 70 & 70.0 \\
\cline { 2 - 4 } & Total & 100 & 100.0 \\
\hline
\end{tabular}

Source: Processed products of SPSS 25

Based on the description above, it is known that the respondents consisted of $30 \%$ male respondents or $30 \%$ and $70 \%$ female respondents or as many as 70 people. From these data, it can be seen that most of the guests who have visited Yogo Living World are dominated by women. Kartajaya (2014) in his book entitled New Wave Marketing, mentions one of the potential new target markets is women, because women are said to be more consumptive than men.

Table 3. Age

\begin{tabular}{rlrr}
\hline & Frequency & Percent \\
\hline \multirow{5}{*}{ Valid } & 15-20 years & 8 & 8.0 \\
& 21-25 years & 86 & 86.0 \\
& 26-30 years & 2 & 2.0 \\
& 31-35 years & 1 & 1.0 \\
& >35 years & 3 & 3.0 \\
& Total & 100 & 100.0 \\
\hline
\end{tabular}

Source: Processed products of SPSS 25

Tourism Research Journal, Volume 5 (1), 2021 
The table above illustrates the age of the respondents who consumed Yogo. From this table it can be seen that the respondents aged $15-20$ years were $8 \%$ or as many as 8 people, then respondents aged $21-25$ years were $86 \%$ or as many as 86 people, then respondents aged 26-30 years were $2 \%$ or as much 2 people, for respondents aged 31-35 years as much as $1 \%$ or as many as 1 person, while respondents who are over 35 years old are $3 \%$ or as many as 3 people. From the data above, it can be concluded that the majority of respondents are 21-25 years old. This is supported by the large number of contemporary drink enthusiasts among students who prefer to hang out with friends.

Table 4. Occupation

\begin{tabular}{clrr}
\hline & Frequency & Percent \\
\hline Valid & Student & 75 & 75.0 \\
& Employees & 11 & 11.0 \\
Housewife & 2 & 2.0 \\
Entrepreneur & 9 & 9.0 \\
And others & 3 & 3.0 \\
Total & 100 & 100.0 \\
\hline
\end{tabular}

Source: Processed products of SPSS 25

In the table above, it can be seen from the number of respondents that it is known that respondents who work as students or as many as 75 people, then respondents who work as employees are $11 \%$ or as many as 11 people. Then for respondents who work as housewives as much as $2 \%$ or as many as 2 people, for respondents who work as entrepreneurs as many as $9 \%$ or as many as 9 people, while respondents with other professions are as many as 3\% or as many as 3 people. From the data above, it can be concluded that the respondents are students.

Table 5. Income

\begin{tabular}{|l|l|l|l|}
\hline \multicolumn{2}{|c|}{} & Frequency & Percent \\
\hline \multirow{4}{*}{ Valid } & $<1$ million & 22 & 22.0 \\
\cline { 2 - 4 } & $1-2$ million & 30 & 30.0 \\
\cline { 2 - 4 } & $3-4$ million & 24 & 24.0 \\
\cline { 2 - 4 } & $5-6$ million & 7 & 7.0 \\
\cline { 2 - 4 } & $>6$ million & 17 & 17.0 \\
\cline { 2 - 4 } & Total & 100 & 100.0 \\
\hline
\end{tabular}

Source: Processed products of SPSS 25

The table above illustrates the income that respondents generate in a month. From this data, respondents with an income of less than 1 million rupiah were $22 \%$ or as many as 22 people, then respondents with an income of 1,000,000-2,000,000 rupiah were $30 \%$ or as many as 30 people, then respondents with an income of $3,000,000-4,000.24 \%$ or as many as 24 people, for respondents with an income of

Tourism Research Journal, Volume 5 (1), 2021 
$5,000,000-6,000,000$ rupiah $7 \%$ or as many as 7 people, while respondents with an income of more than 6 million rupiah were $17 \%$ or as many as 17 people. It can be concluded that most of the respondents have low income due to the affordable price of the product at the initial price and most of the respondents are still students or university students.

Table 6. The Frequency of Visits

\begin{tabular}{|l|l|r|r|}
\hline \multicolumn{2}{|c|}{} & \multicolumn{1}{|c|}{ Frequency } & Percent \\
\hline \multirow{4}{*}{ Valid } & $<2$ times & 74 & 74.0 \\
\cline { 2 - 4 } & $2-3$ times & 15 & 15.0 \\
\cline { 2 - 4 } & $4-5$ times & 4 & 4.0 \\
\cline { 2 - 4 } & $>5$ times & 7 & 7.0 \\
\cline { 2 - 4 } & Total & 100 & 100.0 \\
\hline
\end{tabular}

Source: Processed products of SPSS 25

From the table above, it explains the frequency of the respondents' monthly visits to Yogo Living World. From these data, respondents with a frequency of visits $<2$ times were $74 \%$ or as many as 74 people, then respondents with a frequency of visits of 2-3 times were $15 \%$ or as many as 15 people, then respondents with a frequency of visits were as many as 15 visits. $4-5$ visits were $4 \%$ or as many as 4 people, while respondents with a frequency of visits more than 5 times were $7 \%$ or as many as 7 people. From the table of the results of these calculations it can be concluded that the frequency of majority respondent visits $<2$ times a month.

Table 7. Frequency of Respondents' Instagram Visits

\begin{tabular}{|c|l|r|r|}
\hline \multicolumn{2}{|c|}{} & \multicolumn{1}{|c|}{ Frequency } & Percent \\
\hline \multirow{4}{*}{ Valid } & $<2$ times & 56 & 56.0 \\
\cline { 2 - 4 } & $2-3$ times & 26 & 26.0 \\
\cline { 2 - 4 } & $4-5$ times & 7 & 7.0 \\
\cline { 2 - 4 } & $>5$ times & 11 & 11.0 \\
\cline { 2 - 4 } & Total & 100 & 100.0 \\
\hline
\end{tabular}

Source: Processed products of SPSS 25

The results above explain the frequency of respondents' Instagram visits to Yogo Living World. From these data, respondents with a frequency of visits $<2$ times were $56 \%$ or as many as 56 people, then respondents with a frequency of visits of 2 3 times were $26 \%$ or 26 people, then respondents with a frequency of visits of 2 times were 26 people. $7 \%$ or as many as 7 visits $4-5$ times, while the respondents with a frequency of visits more than 5 times were $11 \%$ or as many as 11 people. From the table of the results of these calculations it can be concluded that the frequency of majority respondent visits $<2$ times a month. 


\section{Validity and Reliability Test Results}

Table 8. Validity Test Promotion of Instagram Variable

\begin{tabular}{|c|c|c|c|}
\hline Question Item & r-table & $\begin{array}{c}\text { Corrected Item } \\
\text { Total Correlation }\end{array}$ & Remark \\
\hline Hashtag $\left(\mathrm{X}_{1}\right)$ & 0.165 & 0.612 & Valid \\
\hline Hashtag $\left(\mathrm{X}_{2}\right)$ & 0.165 & 0.689 & Valid \\
\hline Geotag $\left(\mathrm{X}_{3}\right)$ & 0.165 & 0.645 & Valid \\
\hline Geotag $\left(\mathrm{X}_{4}\right)$ & 0.165 & 0.774 & Valid \\
\hline Follow $\left(\mathrm{X}_{5}\right)$ & 0.165 & 0.639 & Valid \\
\hline Follow $\left(\mathrm{X}_{6}\right)$ & 0.165 & 0.887 & Valid \\
\hline Share $\left(\mathrm{X}_{7}\right)$ & 0.165 & 0.708 & Valid \\
\hline Share $\left(\mathrm{X}_{8}\right)$ & 0.165 & 0.753 & Valid \\
\hline Like $\left(\mathrm{X}_{9}\right)$ & 0.165 & 0.662 & Valid \\
\hline Like $\left(\mathrm{X}_{10}\right)$ & 0.165 & 0.724 & Valid \\
\hline Like $\left(\mathrm{X}_{11}\right)$ & 0.165 & 0.693 & Valid \\
\hline Comment $\left(\mathrm{X}_{12}\right)$ & 0.165 & 0.691 & Valid \\
\hline Comment $\left(\mathrm{X}_{13}\right)$ & 0.165 & 0.743 & Valid \\
\hline
\end{tabular}

Source: Processed products of SPSS 25

Table 9. Validity Test Purchase Interest Variable

\begin{tabular}{|c|c|c|c|}
\hline Question Item & r-table & $\begin{array}{c}\text { Corrected Item } \\
\text { Total Correlation }\end{array}$ & Remark \\
\hline Transactional Interests $\left(\mathrm{Y}_{1}\right)$ & 0.165 & 0.772 & Valid \\
\hline Transactional Interests $\left(\mathrm{Y}_{2}\right)$ & 0.165 & 0.673 & Valid \\
\hline Relative Interests $\left(\mathrm{Y}_{3}\right)$ & 0.165 & 0.756 & Valid \\
\hline Relative Interests $\left(\mathrm{Y}_{4}\right)$ & 0.165 & 0.668 & Valid \\
\hline Preferential Interests $\left(\mathrm{Y}_{5}\right)$ & 0.165 & 0.791 & Valid \\
\hline Preferential Interests $\left(\mathrm{Y}_{6}\right)$ & 0.165 & 0.802 & Valid \\
\hline Interests in Exploration $\left(\mathrm{Y}_{7}\right)$ & 0.165 & 0.699 & Valid \\
\hline Interests in Exploration $\left(\mathrm{Y}_{8}\right)$ & 0.165 & 0.782 & Valid \\
\hline
\end{tabular}

Source: Processed products of SPSS 25

Based on the results of data processing, the calculated $r$ value of all statements is more than 0.165. If $\mathrm{r}$ count is positive and $\mathrm{r}$ count $>\mathrm{r}$ table then all statements in variable $\mathrm{X}$ are valid. Likewise, the variable $\mathrm{Y}$ shows the calculated $\mathrm{r}$ value of more than 0.165 ( $\mathrm{r}$ table). If $\mathrm{r}$ count is positive and $\mathrm{r}$ count $>\mathrm{r}$ table then the variable is declared valid. So from the variable it can be seen that 8 questions related to $\mathrm{Y}$ (purchase interest) are declared valid. 
Table 10. Reliability Test Promotion of Instagram

\begin{tabular}{|c|c|}
\hline Cronboach's Alpha & N of Items \\
\hline .947 & 12 \\
\hline
\end{tabular}

Source: Processed products of SPSS 25

Table 11. Reliability Test Purchase Interest

\begin{tabular}{|c|c|}
\hline Cronboach's Alpha & N of Items \\
\hline .965 & 9 \\
\hline
\end{tabular}

Source: Processed products of SPSS 25

To test the reliability, it shows that the Cronbach's Alpha value for variable $\mathrm{X}$ is 0.947 and variable $\mathrm{Y}$ is 0.965 which is greater than 0.6 , so that the second variable in this study is reliable.

\section{Yogo Instagram analysis}

Respondents' responses to instagra social media can be seen in the table below.

Table 12. The Instagram Variable Average Value Test

\begin{tabular}{|c|c|c|c|c|}
\hline $\begin{array}{c}\text { Sub } \\
\text { Variable }\end{array}$ & Statement & Mean & $\begin{array}{l}\text { Total } \\
\text { Mean }\end{array}$ & Remark \\
\hline \multirow[t]{2}{*}{ Hashtag } & $\begin{array}{l}\text { I use the hashtag } \\
\text { \#LetsSwitchToYOGO to see reviews } \\
\text { from people who come to Yogo Living } \\
\text { World }\end{array}$ & 3.28 & 3.34 & $\begin{array}{c}\text { Quite } \\
\text { Interesting }\end{array}$ \\
\hline & $\begin{array}{l}\text { I will use the hashtag } \\
\text { \#LetsSwitchToYOGO when I post } \\
\text { photos of the drinks I have bought }\end{array}$ & 3.40 & & \\
\hline \multirow[t]{2}{*}{ Geotag } & $\begin{array}{l}\text { Geotags (Instagram location link) help } \\
\text { me gather photo information about } \\
\text { drinks and outlets from people who } \\
\text { come to Yogo Living World }\end{array}$ & 3.94 & \multirow[t]{2}{*}{3.92} & \multirow[t]{2}{*}{ Interesting } \\
\hline & $\begin{array}{l}\text { Geotags (Instagram location link) gave } \\
\text { me instructions on how to find Yogo } \\
\text { Living World locations }\end{array}$ & 3.90 & & \\
\hline \multirow[t]{2}{*}{ Follow } & $\begin{array}{l}\text { By following Instagram "its.yogo" I got } \\
\text { information about the variants of } \\
\text { drinks sold by Yogo Living World }\end{array}$ & 3.99 & \multirow[t]{2}{*}{4.07} & \multirow[t]{2}{*}{ Interesting } \\
\hline & $\begin{array}{l}\text { By following Instagram "its.yogo" I got } \\
\text { information about the promotion of } \\
\text { Yogo Living World }\end{array}$ & 4.15 & & \\
\hline Share & $\begin{array}{l}\text { The Instagram Sharing Tool makes it } \\
\text { easy for me to share experiences or } \\
\text { information in the feed about } \\
\text { Instagram "its.yogo" }\end{array}$ & 3.93 & 3.96 & Interesting \\
\hline
\end{tabular}

Tourism Research Journal, Volume 5 (1), 2021 


\begin{tabular}{|c|c|c|c|c|}
\hline & $\begin{array}{l}\text { Share tools Instagram membantu saya } \\
\text { membagikan pengalaman atau } \\
\text { informasi di Instastory tentang } \\
\text { Instagram "its.yogo" }\end{array}$ & 3.99 & & \\
\hline \multirow[t]{3}{*}{ Like } & $\begin{array}{l}\text { Like Instagram helps me see the } \\
\text { popularity of Yogo Living World on } \\
\text { Instagram "its.yogo" }\end{array}$ & 3.89 & \multirow[t]{3}{*}{3.78} & \multirow[t]{3}{*}{ Interesting } \\
\hline & $\begin{array}{l}\text { Like Instagram helps me find out what } \\
\text { my favorite drink / drink is at Yogo } \\
\text { Living World }\end{array}$ & 3.81 & & \\
\hline & $\begin{array}{l}\text { I found Instagram "its.yogo" or Yogo } \\
\text { photos to browse Instagram that my } \\
\text { friends or relatives love }\end{array}$ & 3.64 & & \\
\hline \multirow[t]{2}{*}{ Comment } & $\begin{array}{l}\text { I came to Yogo Living World because } \\
\text { many followers on Instagram } \\
\text { "its.yogo" gave interesting reviews }\end{array}$ & 3.65 & \multirow[t]{2}{*}{3.78} & \multirow[t]{2}{*}{ Interesting } \\
\hline & $\begin{array}{l}\text { I think the comments column provides } \\
\text { information about the experiences of } \\
\text { someone who has visited Yogo Living } \\
\text { World }\end{array}$ & 3.91 & & \\
\hline \multicolumn{2}{|c|}{ Total Promotion of Instagram Variables } & 3.81 & \multicolumn{2}{|c|}{ Interesting } \\
\hline
\end{tabular}

\section{Purchase Intention Analysis}

The results of the analysis of the respondents' buying interest can be seen in the table below.

Table 13. Average Value of Purchase Interest Variable

\begin{tabular}{|c|c|c|c|c|}
\hline Sub Variable & Statement & Mean & $\begin{array}{l}\text { Total } \\
\text { Mean }\end{array}$ & Remark \\
\hline \multirow[t]{2}{*}{$\begin{array}{l}\text { Transactional } \\
\text { Interests }\end{array}$} & $\begin{array}{l}\text { I came to Yogo Living World } \\
\text { because I saw posts from family, } \\
\text { friends and relatives on Instagram }\end{array}$ & 3.68 & \multirow[t]{2}{*}{3.77} & \multirow[t]{2}{*}{ Interesting } \\
\hline & $\begin{array}{l}\text { After trying the products sold by } \\
\text { Yogo Living World, I feel satisfied } \\
\text { and want to come back again }\end{array}$ & 3.86 & & \\
\hline \multirow[t]{2}{*}{$\begin{array}{l}\text { Relative } \\
\text { Interests }\end{array}$} & $\begin{array}{l}\text { I would recommend Yogo to } \\
\text { family, friends and relatives }\end{array}$ & 3.88 & \multirow[t]{2}{*}{3.87} & \multirow[t]{2}{*}{ Interesting } \\
\hline & $\begin{array}{l}\text { I will share my experience on } \\
\text { Instagram after coming and buying } \\
\text { products at Yogo Living World }\end{array}$ & 3.85 & & \\
\hline $\begin{array}{l}\text { Preferential } \\
\text { Interests }\end{array}$ & $\begin{array}{l}\text { After trying the products sold by } \\
\text { Yogo Living World, I feel that the } \\
\text { taste, appearance and service are } \\
\text { what I paid for }\end{array}$ & 3.93 & 3.93 & Interesting \\
\hline
\end{tabular}

Tourism Research Journal, Volume 5 (1), 2021 


\begin{tabular}{|c|c|c|c|c|}
\hline & $\begin{array}{l}\text { After trying the products sold by } \\
\text { Yogo Living World, I feel that the } \\
\text { product suits my taste }\end{array}$ & 3.92 & & \\
\hline \multirow[t]{2}{*}{$\begin{array}{l}\text { Interests in } \\
\text { Exploration }\end{array}$} & $\begin{array}{l}\text { Before coming to Yogo Living } \\
\text { World, I looked for information } \\
\text { about products sold on Instagram } \\
\text { "its.Yogo" }\end{array}$ & 3.93 & 3.91 & \multirow[t]{2}{*}{ Interesting } \\
\hline & $\begin{array}{l}\text { Before trying Yogo Living World, } \\
\text { I looked for a menu or beverage } \\
\text { product that was almost the same } \\
\text { or similar to "its.yogo" and } \\
\text { compared them on Instagram }\end{array}$ & 3.89 & & \\
\hline \multicolumn{2}{|c|}{ Total Purchase Intention Variables } & 3.87 & \multicolumn{2}{|c|}{ Interesting } \\
\hline
\end{tabular}

Source: Processed products of SPSS 25

The total value of the mean (average) test for the Instagram promotion variable and the promotion interest variable is 3.81 and 3,87 which is categorized as fairlygood. This is caused by several factors, one of which is the customer has his own reference. to see reviews from people who have come and how rarely do people use hashtags after posting photos of existing drinks. Instagram promotion is proven to have an effect on consumer buying interest that displays Hashtags, Geotags, Follow, Share, Like and Comment. The better the Instagram promotion that is given, the better it will be in influencing consumer buying interest.

\section{Determination Coefficient Test Results}

Table 14. Test Results of The Coefficient Of Determination Model Summary

\begin{tabular}{lrrrr}
\hline Model & R & R Square & $\begin{array}{c}\text { Adjusted R } \\
\text { Square }\end{array}$ & $\begin{array}{l}\text { Std. Error of } \\
\text { the Estimate }\end{array}$ \\
\hline 1 & $.862^{\mathrm{a}}$ & .744 & .741 & 3.49267 \\
a. Predictors: (Constant), X & & \\
\hline
\end{tabular}

Source: Processed products of SPSS 25

From table $4: 35$, it can be seen that the Adjusted R Square number is 0.741 , which means that the promotion of Instagram variable has an influence of $74.1 \%$ on the purchase intention variable. While the remaining $25.9 \%$ is influenced by other factors not examined in this study. 


\section{Simple Linear Regression Test Results}

Table 15. Simple Linear Regression

Coefficients $^{\mathrm{a}}$

\begin{tabular}{|c|c|c|c|c|c|c|}
\hline \multirow[b]{2}{*}{ Model } & & \multicolumn{2}{|c|}{$\begin{array}{c}\text { Unstandardized } \\
\text { Coefficients }\end{array}$} & $\begin{array}{c}\text { Standardized } \\
\text { Coefficients }\end{array}$ & \multirow[b]{2}{*}{$\mathrm{t}$} & \multirow[b]{2}{*}{ Sig. } \\
\hline & & B & Std. Error & Beta & & \\
\hline \multirow[t]{2}{*}{1} & (Constant) & 6.134 & 1.512 & & 4.056 & .000 \\
\hline & $\mathrm{X}$ & .501 & .030 & .862 & 16.856 & .000 \\
\hline \multicolumn{7}{|c|}{ a. Dependent Variable: Y } \\
\hline
\end{tabular}

Source: Processed products of SPSS 25

From the table above, the regression equation formed is as follows:

$$
\mathrm{Y}=6.134+0.501 \mathrm{x}
$$

The results of the regression equation show a constant value of 6,134 , meaning that if the promotion of Instagram is 0 , the value of consumer buying interest will reach 6,134 . The regression coefficient on the promotion variable is 0.501 , meaning that if there is an increase in 1 unit of the Instagram variable, there will be an increase in consumer buying interest by 0.501 .

\section{Hypothesis Test-T Test}

The $\mathrm{t}$ test is performed with $\alpha=5 \%$, then the table is 1.66023. In table 11 the $t$ promotion of Instagram is 16.856 , which means it is greater than the table value of 1.666023 and a probability value of 0.000 , which means less than 0.05 , then $\mathrm{H}_{0}$ is rejected and $\mathrm{Ha}$ is accepted or the Instagram value variable has a significant effect. about buying interest.

\section{E. Discussion}

Based on data testing using statistics, the t-count results are 16.856 greater than $\mathrm{t}$-table $=1.66023$, so it can be concluded that Instagram Promotion has a significant effect on Consumer Purchase Interest at Yogo Living World.

This means that the higher the Instagram promotion variable, the better consumer interest in Yogo Living World. If Instagram promotions are used properly, consumer buying interest is also good, this is influenced by Instagram promotions which post and upload pictures and photos of goods sold by Yogo Living World properly and attractively and fairly to all consumers, and respond to consumer comments, this is proven by facts in the field. Consumers' buying interest, initially just looking around, then interested in the post, then began to comment on every Yogo Living World Instagram promotion post, this has influenced the consumer's buying interest. This means that the better and more interesting posts in the form of videos, photos and captions on Instagram promotions, the consumer's buying interest will increase to buy the items they see.

Instagram promotion applications that display sharing photos or images are proven to have a strong correlation in influencing consumer buying interest. It is

Tourism Research Journal, Volume 5 (1), 2021 
known that the correlation value between Instagram promotion and purchase intention is $74.1 \%$, the correlation value is positive, meaning that the relationship between the two variables is the same as the more effective Instagram promotion is, the higher the consumer's influence. buying interest.

\section{F. Conclusions And Suggestions \\ Conclusion}

It can be concluded that by following Instagram "its, yogo" can attract consumers to find out about existing promotions. When people considering Instagram interesting, it will increase consumer purchase interest in the taste, appearance, and services provided at Yogo Living World.

The results of the coefficient of determination test, showed the Instagram variable contributes $74.4 \%$ on the purchase interest variable. Meanwhile, another $25.6 \%$ was influenced by other factors which were not examined in this study. Additionally, the regression equation showed that there is a significant influence of Instagram on consumer purchase interest. Therefore, the culinary business promoted through social media, especially Instagram, which can describe product profiles ranging from taste, appearance and service through videos displayed on social media.

\section{Suggestion}

Recommended to be more active in using hashtags on every photo posted on Instagram to increase consumers. buying interest by: adding variations of hashtags, number of hashtags, and providing special promotions for customers who use hashtags. In addition, it is also advisable to give away on Instagram by way of customers posting product photos from Instagram "its.yogo" with the aim that product photos can be displayed and seen by Instagram followers who have posted "its.yogo". Photo. Therefore, people are curious on to seek the existing products, and it can reach a wider community.

\section{REFERENCES}

Aji, P. M., Nadhila, V., \& Sanny, L. (2020). Effect of Social Media Marketing on Instagram Towards Purchase Intention: Evidence From Indonesia's Readyto-Drink Tea Industry. International Journal of Data and Network Science, 4: $91-$ 104.

Appel, G., Grewel, L., Hadi, R., \& Stephen, A. T. (2019). The future of social media in marketing. Journal of the Academy of Marketing Science, 48: 79-95.

Astuti, B., \& Putri, A. P. (2018). Analysis on the Effect of Instagram Use on Consumer Purchase Intensity. Review of Integrative Business and Economic, 7(2): 2438.

Atmoko, D. B. (2012). Instagram Handbook Tips Fotografi Ponsel. Jakarta: MediaKita.

Tourism Research Journal, Volume 5 (1), 2021 
Bostanshirin, S. (2014). Online Marketing: Challenges and Opportunities. Proceedings of Socioint14- International Conference on Social Sciences and Humanities, 783-792.

Durianto. (2013). Strategi Menaklukan Pasar Melalu Riset Ekuitas Perilaku Merek. Jakarta: PT. Gramedia.

Halilkainen, H., Savimaki, E., \& Laukkanen, T. (2020). Fostering B2B Sales With Customer Big Data Analytics. Industrial Marketing Management, 86: 90-98.

Huang, O., \& Copeland, L. (2020). Gen Z, Instagram Influencers, And Hashtags' Influence On Purchase Intention Of Apparel. Academy of Marketing Studies Journal, 24(3): 1-14.

Ibrahim, S., \& Ganeshbabu, P. (2018). A Study on the Impact of Social Media Marketing Trends on Digital Marketing. International Journal of Management, 6(1): 120-125.

Jackson, G., \& Ahuja, V. (2016). Dawn of The Digital Age and The Evolution of The Marketing Mix. Journal of Direct, Data and Digital Marketing Practice, 17(3): 170186.

Kertajaya, H. (2014). WOW Marketing. Jakarta: Gramedia Pustaka Utama.

Kaplan, A. M., \& Haenlein, M. (2010). Users of the world, unite The Challenges and Opportunities of Social Media. Business Horizons, 53(1): 59- 68.

Kotler, P., \& Keller. K. L. (2012). Marketing Management. New Jersey: Pearson Education.

Nangoy, C. L., \& Tumbuan, W. J. F. A. (2018). The Effect of Advertising and Sales Promotion on Consumer Buying Decision of Indovision TV Cable Provider. Jurnal Emba, 6(2): 1228-1237.

NapoleonCat. (2021). Instagram Users in Indonesia. Retrieved February 1, 2021, from https://napoleoncat.com/stats/instagram-users-in-indonesia/2021/02.

Nasrullah, R. (2015). Media Sosial. Bandung: PT Remaja Rosdakarya.

Negara, A.A. N. D. E., Arifin, Z., \& Nuralam, I. P. (2018). Pengaruh Kualitas Produk Dan Brand Image Terhadap Minat Beli. Jurnal Administrasi Bisnis, 61(2): 202209.

Puntoadi, D. (2011). Meningkatkan Penjualan Melalui Social Media. Jakarta: ElexGramedia.

Quinton, S. (2013). The Community Brand Paradigm: a Response to Brand Management's Dilemma in The Digital Era. Journal of Marketing Management, 29 (7-8): 912-932.

Rahmah, K., Sumarwan, U., \& Najib, M. (2018). The Effect of Brand Equity, Marketing Mix, and Lifestyle Toward Purchase Decision at Coffee Shop in Bogor. Journal of Consumer Sciences, 3(2): 1-15.

Silvia, S. (2019). The Importance of Social Media and Digital Marketing to Attract Millennials' Behavior as a Consumer. Journal of International Business Research and Marketing, 4 (2): 7-10. 